\title{
Ghrelin stimulation by hypothalamic-pituitary-adrenal axis activation depends on increasing cortisol levels
} Endocrine CONNECTIONS

\author{
I Azzam 1', S Gilad', R Limor', N Stern ${ }^{1,2}$ and Y Greenman ${ }^{1,2}$ \\ ${ }^{1}$ Institute of Endocrinology, Metabolism and Hypertension, Tel Aviv-Sourasky Medical Center, Tel Aviv, Israel \\ ${ }^{2}$ Sackler Faculty of Medicine, Tel Aviv University, Tel Aviv, Israel
}

Correspondence should be addressed

to $\mathrm{Y}$ Greenman

Email

yonagr@tlvmc.gov.il

\begin{abstract}
Ghrelin plasma concentration increases in parallel to cortisol after a standardized psychological stress in humans, but the physiological basis of this interaction is unknown. We aimed to elucidate this question by studying the ghrelin response to pharmacological manipulation of the hypothalamic-pituitary-adrenal (HPA) axis. Six lean, healthy male volunteers were examined under four experimental conditions. Blood samples were collected every 30 min for two sequential periods of two hours. Initially, a baseline period was followed by intravenous injection of a synthetic analog of ACTH $(250 \mu \mathrm{g})$. Subsequently, a single dose of metyrapone was administered at midnight and in the following morning, blood samples were collected for $2 \mathrm{~h}$, followed by an intravenous injection of hydrocortisone $(100 \mathrm{mg})$ with continued sampling. We show that increased cortisol serum levels secondary to ACTH stimulation or hydrocortisone administration are positively associated with plasma ghrelin levels, whereas central stimulation of the HPA axis by blocking cortisol synthesis with metyrapone is associated with decreased plasma ghrelin levels. Collectively, this suggests that HPA-axis-mediated elevations in ghrelin plasma concentration require increased peripheral cortisol levels, independent of central elevation of ACTH and possibly CRH levels.
\end{abstract}

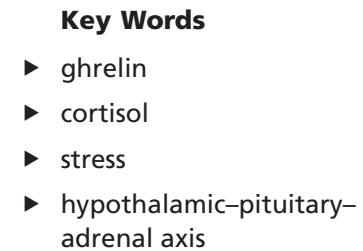

Endocrine Connections (2017) 6, 847-855

\section{Introduction}

Ghrelin is a major regulator of food intake, energy balance and body weight (1). The active form of ghrelin, acylghrelin, is the endogenous ligand for the growth hormone secretagogue receptor (GHSR)1a (2). Since its cloning (3), ghrelin was found to be involved in a myriad of additional physiologic functions $(4,5,6,7)$. Ghrelin plays an important role in the activation of central pathways mediating stress-induced food reward behavior $(8,9,10$, 11 ) and is also involved in the response to acute stressors such as major surgery (12) and stress-induced gastric mucosal injury $(13,14)$. Ghrelin stimulates the secretion of hormones involved in the stress response, including vasopressin, ACTH, prolactin and cortisol $(15,16,17)$. The stimulation of the HPA axis by ghrelin is exerted predominantly at the hypothalamic level (18) through vasopressin stimulation (19) and indirect activation of CRH neurons $(20,21)$. Direct effects of ghrelin on pituitary ACTH $(3,22)$ and adrenal cortisol secretion (23, $24,25)$ are minor, despite abundant GHSR1a expression in these tissues (26). Studies using hexarelin, a synthetic GH secretagogue (GHS) that activates GHSR1a, suggest that the stimulatory effect of GHS on corticotroph function is sensitive to glucocorticoid feedback, as the ACTH response to hexarelin was suppressed by pre-treatment
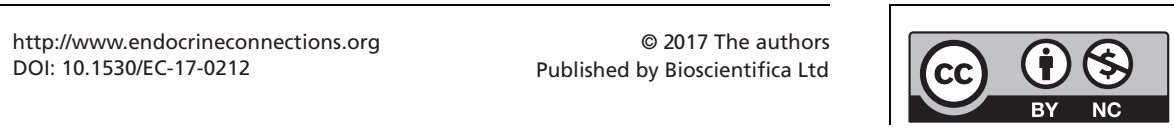

This work is licensed under a Creative Commons Attribution-NonCommercial 4.0 International License. 
with dexamethasone (27) but enhanced in patients with Addison's disease and in healthy subjects pre-treated with metyrapone (28).

In contrast to the expanding knowledge on ghrelin's biological functions, the regulation of ghrelin's synthesis and secretion is less well characterized, although involvement of the autonomic nervous system $(29,30)$ and peptides such as somatostatin and bombesin (31) have been reported. Both acute (32) and chronic psychological stresses (9) are associated with increased ghrelin secretion in animal models. It has been hypothesized that this stressinduced ghrelin rise may be mediated by the increased sympathoadrenal tone characteristic of the stress response, through stimulation of $\beta_{1}$-adrenergic receptors on gastric ghrelin cells $(33,34)$. The corticosterone response to an acute stress was reduced in ghrelin (35) and in ghrelin receptor knock-out mice (9), indicating that a fraction of the stress-induced corticosterone secretion is mediated through ghrelin and its receptor.

In a previous study, we showed for the first time in humans that a standardized psychological challenge may induce an increase in plasma total ghrelin concentration (36), and that the stress-induced increase in plasma ghrelin was positively correlated with the serum cortisol response. Although the HPA activation by stress was paralleled by an increase in plasma ghrelin levels, we could not establish whether this was a direct effect or was rather mediated by the activation of other factors. To try to elucidate this question, we studied the ghrelin response to direct activation at various levels of the HPA axis in humans, through standard tests used in clinical practice.

\section{Subjects and methods}

\section{Subjects}

Subjects were recruited by advertizing in bulletin boards at our institution. Six healthy subjects gave written informed consent to participate in the study after receiving full explanation of the purpose and nature of all procedures. Inclusion criteria were as follows: age between 18 and 75 years, male gender and BMI between 20 and $30 \mathrm{~kg} / \mathrm{m}^{2}$. Women have been shown to have higher ghrelin levels than men; therefore, female volunteers were not included in order to obtain a homogeneous study group. Subjects with any type of chronic or acute disease, history of alcohol or drug abuse or individuals taking medications were excluded. The study was approved by the Ethical
Committee of the Tel Aviv-Sourasky Medical Center, functioning according to the 3rd edition of the Guidelines on the Practice of Ethical Committees in Medical Research issued by the Royal College of Physicians of London.

\section{Study protocol}

Dynamic hormone testing was performed at the daycare facilities of the Institute of Endocrinology, Metabolism and Hypertension at our institution on two different occasions, one week apart. Blood pressure, weight, height, BMI and waist and hip circumference were measured in all subjects upon arrival on experimental day 1. Testing was started at 09:00h, while subjects remained in the fasting state throughout the day. Blood samples were collected for baseline measurements of cortisol, ACTH, total ghrelin and acyl-ghrelin at 30-min intervals for two hours. Glucose, insulin and lipid profile were also tested at baseline. Subsequently, a standard synacthen test was performed (intravenous injection of $250 \mu \mathrm{g}$ Cosyntropin (tetracosactide - beta1-24-corticotrophin, Sigma-Tau, Issy-les-Moulineaux, France) and blood samples were collected again for the same hormonal measurements every $30 \mathrm{~min}$ for two additional hours. After one-week interval, a standard metyrapone test was conducted: Metyrapone ( $2 \mathrm{~g}$ for subjects weighting less than $70 \mathrm{~kg}$, and $2.5 \mathrm{~g}$ for subjects with weights between 70 and $90 \mathrm{~kg}$ ) was given at midnight, followed by hormone testing in the subsequent morning. Metyrapone blocks cortisol synthesis by reversibly inhibiting steroid $11 \beta$-hydroxylase, thus stimulating ACTH secretion, which in turn increases plasma 11-deoxycortisol levels. On the following morning (experimental day 2), in the fasting state, blood samples were again collected for baseline levels of cortisol, ACTH, total ghrelin and acyl-ghrelin, starting at 09:00 h for two hours at 30-min intervals. Then, $100 \mathrm{mg}$ hydrocortisone was given intravenously as a slow bolus, and blood samples were obtained again for hormonal measurements for additional two hours at $30 \mathrm{~min}$ intervals. Thus, ghrelin secretion was assessed under four settings in relation to cortisol and ACTH, each lasting two hours: (1) phase 1 - baseline unstimulated cortisol and ACTH levels; (2) phase 2 - high ACTH and cortisol levels after synacthen administration; (3) phase 3 - high ACTH and low cortisol levels in the morning which followed the administration of metyrapone on the preceding night and (4) phase 4 - high cortisol with decreasing ACTH levels after hydrocortisone administration. http://www.endocrineconnections.org
DOI: $10.1530 /$ EC-17-0212
(C) 2017 The authors Published by Bioscientifica Ltd
This work is licensed under a Creative Commons Attribution-NonCommercial 4.0 International License. 


\section{Laboratory measurements}

Blood samples for ghrelin measurements (both total and acyl-ghrelin) were collected in EDTA vacutainer tubes kept in ice. Blood samples were then centrifuged for $15 \mathrm{~min}$ at $4^{\circ} \mathrm{C}$ and the plasma was removed to a polystyrene tube $12 / 75$ kept on ice. Fifty microliters of $1 \mathrm{M} \mathrm{HCL}$ and $10 \mu \mathrm{L}$ of the protease inhibitor phenylmethylsulfonyl fluoride (PMSF, Sigma-Aldrich) were added to each milliliter of plasma to maintain the stability of acyl-ghrelin. Samples were then stored at $-20^{\circ} \mathrm{C}$. Total plasma ghrelin levels (measured both acyl- and des-acyl-ghrelin peptides) were measured with a commercial radioimmunoassay (Merck Millipore), with within- and between-assay coefficients of variation of $<10 \%$, and $17 \%$, respectively. Acyl-ghrelin levels were determined using a commercial radioimmunoassay (Linco Research, Missouri, USA). Within- and between-assay coefficients of variation for this assay were $<9.5 \%$ and $<16.2 \%$, respectively.

Serum cortisol and insulin were measured by electrochemiluminescence immunoassays (ECLIAs) by a Roche-Hitachi Cobas E411 analyzer. ACTH was measured by immunochemiluminescence on an IMMULITE 2000 XPi Immunoassay System. This assay is highly specific for $\mathrm{ACTH}$, with a very low cross-reactivity with 1-24 ACTH (1, 0.5 and $0.2 \%$ when 500, 5000 and 50,000 pg/mL of synacthen are added to the reaction). ACTH levels measured using a radioimmunoassay with an antibody that recognized the N-terminal sequence of ACTH were extremely high in the order of $700 \mathrm{pg} / \mathrm{mL} 30 \mathrm{~min}$ after intravenous administration of synacthen $250 \mu \mathrm{g}$ (37). This implies that measurements of ACTH by the IMMULITE immunoassay cannot reflect the actual levels of bioactive ACTH present in the circulation after synacthen administration; therefore, these measurements were excluded from the analyses. Deoxycortisol and cortisol levels sampled on investigational day 2 (following metyrapone administration) were measured by HPLC, in view of the cross-reactivity between these two hormones $(4.1 \%)$ in the ECLIA. This HPLC method is routinely used in our laboratory and is based on the extraction of serum with methylene chloride after the addition of internal standards and injection on a reverse phase column with UV detection.

Briefly, $100 \mathrm{ng}$ of internal standard, flurandrenolide (SIGMA F1642), in $50 \mu \mathrm{L}$ of ethanol (MERCK lichrosolv 1.11727), is added in glass tubes to standards and samples. A mixture of cortisol (F) and deoxycortisol (S) is added to the standard tubes ( $40 \mathrm{ng}$ of $\mathrm{F}$ and $40 \mathrm{ng}$ of $\mathrm{S}$ in $20 \mu \mathrm{L}$ of ethanol). Three milliliter of methylene chloride (MERCK lichrosolv 1.06044) is added to $200 \mu \mathrm{L}$ of sera as an upper layer in the sample tubes. Samples are immediately mixed on a vortex for $30 \mathrm{~s}$ and centrifuged at $40^{\circ} \mathrm{C}, 1750 \mathrm{~g}$, for $15 \mathrm{~min}$. The infranatant is then transferred into clean $16 \times 100 \mathrm{~mm}$ glass tubes by gentle decanting. The serum phase remains on the walls of the tubes. The sample extracts and non-extracted standards are dried with air at $45^{\circ} \mathrm{C}$ in a ZYMARK TURBO VAP LV evaporator for $5 \mathrm{~min}$. Dried down samples and standards are dissolved in $200 \mu \mathrm{L}$ of mobile phase 58\% methanol (MERCK lichrosolv 1.06007): $42 \% \mathrm{H}_{2} \mathrm{O}$ (MERCK lichrosolv 1.15333) and then transferred to glass inserts in the autosampler. Forty microliters are injected through a MERCK lichrocart RP18/5micrometer $125-4$ column. Detector was set to $254 \mathrm{~nm}$.

Homeostasis model assessment for insulin resistance (HOMA-R) was calculated as (fasting blood glucose $(\mathrm{mg} / \mathrm{dL}) \times$ fasting insulin $(\mathrm{IU} / \mathrm{L})) / 405$.

\section{Statistical analysis}

An analysis of variance with repeated measures (phase and time) was performed for cortisol, ACTH, total ghrelin and acyl-ghrelin levels to assess the change over time and the effect of phase on those parameters. The MIXED procedure in SAS was used for this analysis, and patients' BMI at baseline was included in the analysis as a confounder. Phase $\times$ time analysis was performed for each phase separately (to compare between time points), and phase $\times$ time $\times$ time analysis was performed for the mean of all time points at each phase (to compare between phases). Whenever a significant main effect (phase or time) was noted, Hochberg's method for multiple comparisons was applied for a pairwise comparison between the different levels of this effect.

The association between the above-mentioned parameters was assessed by the Pearson correlation coefficient. They were calculated for each phase separately, once for the means of the parameters over all time points (examining associations of tested parameters between study participants), and once for the area under the curve (AUC) of the levels of parameters at different time points (examining associations between measurements at different time points irrespective of order). AUC was calculated by the trapezoid method. All statistical analyses were performed using SAS for Windows version 9.1. Data are presented as means \pm S.E.M. http://www.endocrineconnections.org DOI: 10.1530/EC-17-0212
○ 2017 The authors Published by Bioscientifica Ltd
This work is licensed under a Creative Commons Attribution-NonCommercial 4.0 International License. 
Table 1 Characteristics of the study population.*

\section{Age (years)}

BMI $\left(\mathrm{kg} / \mathrm{m}^{2}\right)$

LDL cholesterol (mg/dL)

Glucose (mg/dL)

Insulin $(\mu \mathrm{U} / \mathrm{mL})$

HOMA

Basal serum cortisol ( $\mu \mathrm{g} / \mathrm{dL})$

Basal plasma ACTH (pg/mL)

Basal plasma total ghrelin $(\mathrm{pg} / \mathrm{mL})$

Basal plasma acyl-ghrelin (pg/mL)

*Values are mean \pm S.E.M., $n=6$

HOMA-R, Homeostasis Model Assessment for insulin Resistance.

\section{Results}

\section{Demographics}

Six healthy male subjects (mean age $29.7 \pm 6.5$, range 18.5-37 years) participated in the study. Participants had normal body weight (mean BMI $23 \pm 1.67 \mathrm{~kg} / \mathrm{m}^{2}$ ), blood pressure, blood glucose and lipid levels as well as insulin sensitivity as measured by HOMA-R (Table 1).

\section{Mean hormone serum/plasma levels according to experimental phase}

As expected, mean serum cortisol was higher after ACTH stimulation (phase 2) than at the baseline (phase 1). Serum cortisol decreased following metyrapone administration (phase 3) and significantly increased after hydrocortisone injection (phase 4) (Fig. $1 \mathrm{~A}, P=0.008$; and $P=0.02, P=0.01$ and $P=0.01$ for the comparison among phase 1 vs 4 , 2 vs 4 and 3 vs 4 , respectively). Similarly, the expected and concordant changes occurred in plasma ACTH levels, with a very prominent increase after metyrapone administration followed by a gradual decrease after hydrocortisone injection (Fig. $1 \mathrm{~B}, P<0.0001 ; P<0.0001$ for the comparisons among phase 1 vs 3 and 3 vs 4 ). АCTH plasma levels measured after administration of synacthen were excluded from the analyses as they do not accurately reflect the actual levels of the biologically active hormone. There was a significant difference in mean total ghrelin plasma concentration according to study phase $(P=0.031)$ in that levels were significantly lower in the metyrapone phase in comparison with levels after synacthen
Baseline

A

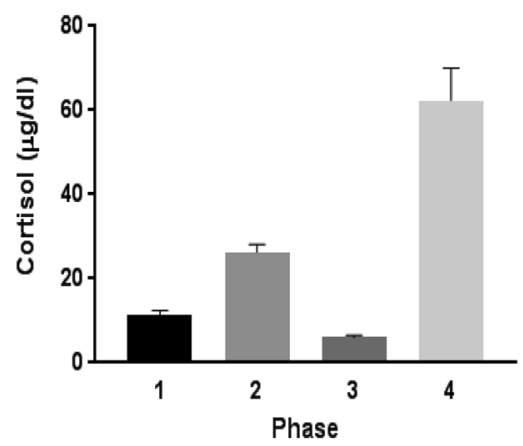

C

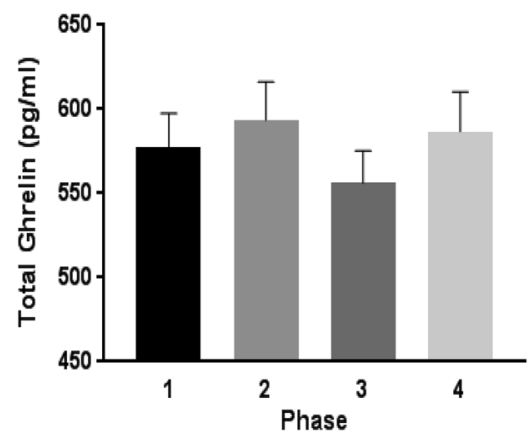

Metyrapone

B

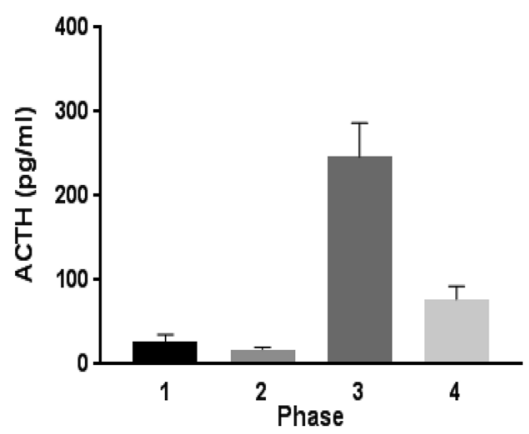

D

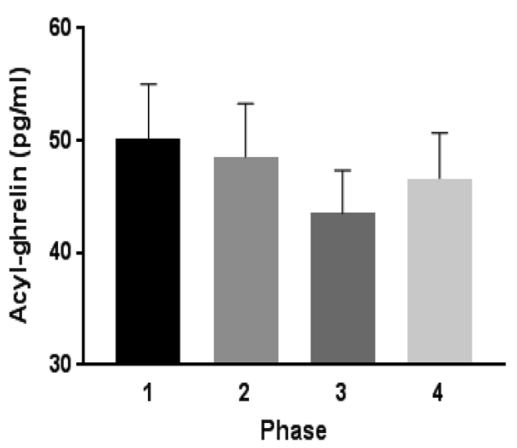

Figure 1

Mean serum cortisol (panel A), mean plasma ACTH (panel B), mean plasma total ghrelin (panel C) and mean plasma acyl-ghrelin (panel D) concentration at baseline and after administration of synacthen, metyrapone or hydrocortisone. Hormone concentrations were measured every $30 \mathrm{~min}$ for two hours in each phase. Test for difference in means between phases: $P=0.008, P<0.001, P=0.031$ and $P=0.057$ for phase comparisons for mean cortisol, ACTH, total ghrelin and acyl-ghrelin, respectively.

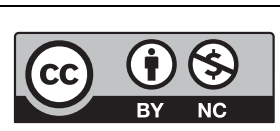

This work is licensed under a Creative Commons Attribution-NonCommercial 4.0 International License. 
Table 2 Correlation between plasma total and acyl-ghrelin concentrations in different study phases.

\begin{tabular}{lllll} 
Phase & & Correlation (means) & & Correlation (AUC) \\
\cline { 1 - 1 } 1- Baseline & & $r=0.961 ; P=0.0022$ & & $r=0.957 ; P=0.027$ \\
2- Synacthen & & $r=0.947 ; P=0.0041$ & & $r=0.939 ; P=0.0055$ \\
3- Metyrapone & & $r=0.898 ; P=0.01$ & & $r=0.915 ; P=0.01$ \\
4- Hydrocortisone & $r=0.96 ; P=0.001$ & & $r=0.96 ; P=0.0024$ \\
\cline { 5 - 6 } & &
\end{tabular}

$(P=0.033)$ and hydrocortisone administration $(P=0.02$, Fig. 1C). There was a borderline difference in mean acylghrelin plasma concentration according to study phase $(P=0.057)$ in that acyl-ghrelin plasma concentration was lower during the metyrapone phase in comparison with baseline ( $P=0.058$, Fig. 1D). There was a strong positive correlation between total and acyl-ghrelin throughout all study phases, as analyzed as mean values as well as AUC (Table 2).

\section{Ghrelin response to stimulation with $250 \mu \mathrm{g}$ synacthen (high ACTH, high cortisol paradigm, phase 2)}

During the initial two-hour baseline time (phase 1), cortisol serum levels decreased, according to the physiological diurnal variation, from $12.6 \pm 3 \mu \mathrm{g} / \mathrm{dL}$ to $9 \pm 4.6 \mu \mathrm{g} / \mathrm{dL}$ $(P=0.043)$, and this decrease was strongly correlated with the decrease in plasma ACTH levels, as expected $(r=0.95$, $P=0.003$, for the correlation between mean cortisol and ACTH values). No significant changes between time points were observed in total and acyl-ghrelin plasma levels during this time period.

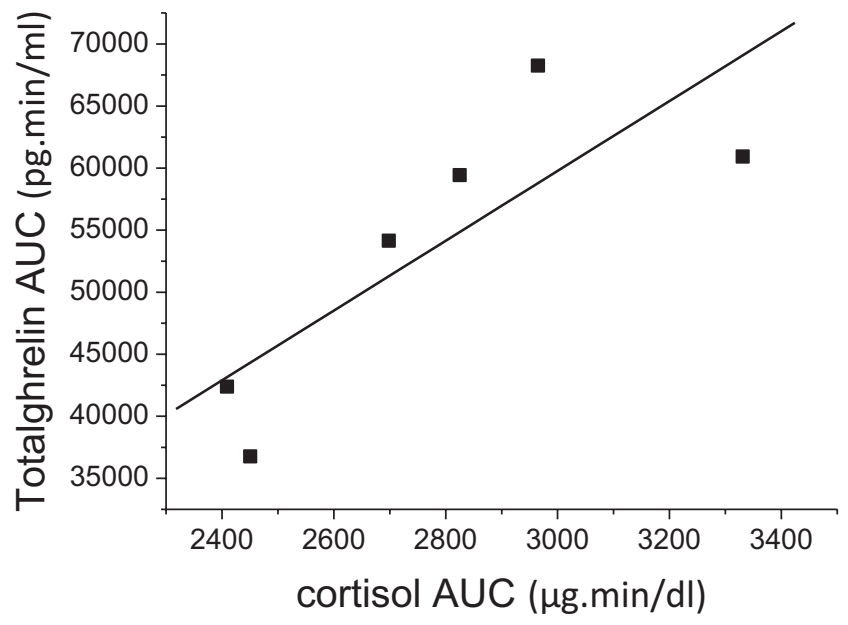

Figure 2

Correlation between total plasma ghrelin and serum cortisol AUCs after direct stimulation with $250 \mu$ g synacthen. $r=0.876, P=0.02$.
Following the administration of synacthen (phase 2), cortisolvalues increased as expected (baseline- $9 \pm 4.6 \mu \mathrm{g} / \mathrm{dL}$; $29.6 \pm 3.1$ and $34.8 \pm 5.4 \mu \mathrm{g} / \mathrm{dL}$ after 60 and $120 \mathrm{~min}$, respectively; $P<0.0001$, but neither total nor acyl-ghrelin plasma concentration changed significantly. Nevertheless, a strong positive correlation was found between the AUC for total ghrelin and cortisol response to synacthen ( $r=0.876, \quad P=0.02$, Fig. 2). Cortisol and acyl-ghrelin levels were also positively correlated but with borderline statistical significance $(r=0.76$ and $P=0.08$ for AUC values).

\section{Ghrelin response to metyrapone (high ACTH, low cortisol paradigm, phase 3)}

Mean baseline cortisol serum levels in the morning following midnight metyrapone administration were $5.3 \pm 2.5 \mu \mathrm{g} / \mathrm{dL}$, mean serum 11-deoxycortisol was $12.6 \pm 3.1 \mu \mathrm{g} / \mathrm{dL}$ and mean plasma ACTH reached $322 \pm 98 \mathrm{pg} / \mathrm{mL}$, indicating an effective inhibition of the 11-hydroxylase enzyme. Mean total and acyl-ghrelin plasma levels were significantly lower in phase 3 (as measured for $2 \mathrm{~h}$ in the morning following midnight metyrapone administration) when compared with other phases $(P=0.031$, Fig. $1 \mathrm{C}$ and $P=0.057$, Fig. $1 \mathrm{D}$ for total and acyl-ghrelin, respectively).

\section{Ghrelin response to an intravenous administration of $100 \mathrm{mg}$ hydrocortisone (high cortisol, decreasing ACTH levels paradigm, phase 4)}

There was a significant increase in plasma acyl-ghrelin levels after hydrocortisone administration from a mean baseline

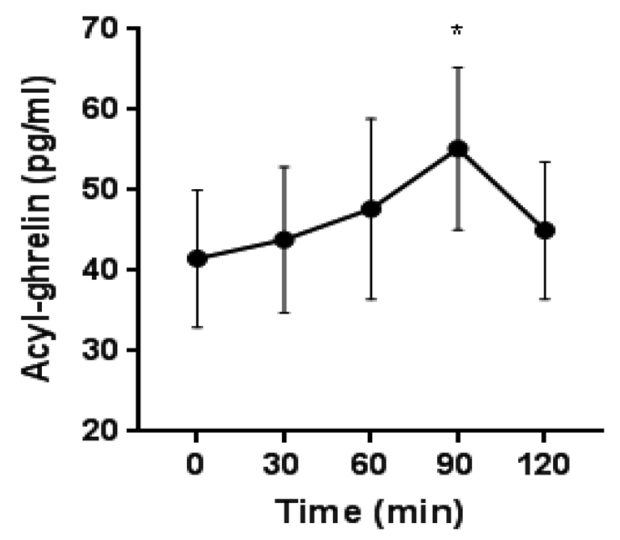

Figure 3

Mean acyl-ghrelin plasma levels after hydrocortisone administration. Repeated measures ANOVA: $P=0.03$ at $90 \mathrm{~min}$ after hydrocortisone administration.

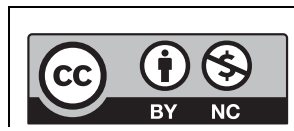

This work is licensed under a Creative Commons Attribution-NonCommercial 4.0 International License. 
plasma concentration of $41.5 \pm 20.8-55.1 \pm 24.7 \mathrm{pg} / \mathrm{mL}$ 90 min post-injection ( $P=0.03$, Fig. 3 ).

\section{Discussion}

In this study, we expand our previous work on the stressrelated correlation between cortisol and ghrelin plasma levels (36) taking it one step forward by dissecting their interaction according to HPA axis activation at different levels. The key finding in the present study is the observation of a positive association between ghrelin/ acyl-ghrelin and cortisol levels, either in the setting of increasing endogenous serum cortisol in response to stimulation by exogenous ACTH (synacthen) or during the rise in serum cortisol induced following the intravenous injection of exogenous hydrocortisone. In contrast, despite extremely elevated ACTH plasma levels reached through inhibition of adrenal cortisol synthesis by metyrapone, ghrelin plasma concentration not only did not rise, but in fact remained at significantly lower levels in comparison with those measured during the other experimental settings. Hence, while increasing circulating cortisol was associated with a rise in plasma ghrelin concentration, central stimulation of the HPA axis in the face of persistently low peripheral cortisol levels (metyrapone challenge) was unable to stimulate ghrelin secretion. Collectively, these findings suggest that ghrelin stimulation secondary to activation of HPA axis does not occur at the hypothalamic level but rather at the periphery, dependent on elevated cortisol serum levels.

It should be noted, however, that despite the emergence of a positive correlation (mean and AUC values) between ghrelin/acyl-ghrelin and cortisol after synacthen administration, ghrelin plasma levels did not change significantly after this stimulus. In contrast, acyl-ghrelin plasma levels increased substantially in parallel to the much higher cortisol serum levels reached following hydrocortisone administration. This may indicate the existence of a dose response or a threshold for ghrelin stimulation by cortisol.

The literature examining the interrelationship between ghrelin and the HPA axis is complex and often discrepant. Results vary depending on context, circumstances and target population in which it was evaluated. For example, during a 12-h nocturnal sampling, a strong positive association between total ghrelin and cortisol secretory dynamics was found in adolescent girls with or without anorexia nervosa (38), but no association was found between nocturnal ghrelin and cortisol levels in healthy men and women (39). There was no correlation between circadian variation of ghrelin and cortisol serum levels when studied in the basal, non-fasted state (40), whereas a strong inverse correlation emerged after prolonged fasting (41). Furthermore, ghrelin and cortisol serum concentrations were positively correlated in the basal fasting state in women with eating disorders, but not in healthy women (42). Finally, although a coldpressor stress test increased ghrelin and cortisol, there was no correlation between the post-stress levels of these hormones (43), in contrast to the strong correlation found between them after a psychological stress (36).

The interaction between ghrelin and the HPA axis was also studied by means of exogenous administration of glucocorticoids. High-dose prednisolone administration for five days to healthy subjects suppressed ghrelin plasma levels by $18 \%$ (44). On the other hand, a fourhour nocturnal hydrocortisone infusion did not affect acyl- or desacyl-ghrelin plasma levels in healthy adults (45). Dexamethasone administration increased ghrelin plasma levels in neonatal rats (46) and stimulated ghrelin expression in rat hypothalamic 4B cells (47). On the other hand, adrenalectomized rats had similar plasma ghrelin levels in the fed state but levels were higher in the fasting state in comparison to sham-operated rats (48).

It seems that no single unifying hypothesis could explain the variety of cortisol-ghrelin interactions observed under such variable experimental settings. From the correlation studies performed in humans, it seems that an interaction between these two hormones was found mainly in fasting states or in patients with eating disorders, situations in which basal ghrelin levels are elevated, but not in the natural fed state or in healthy subjects. Studies in which exogenous glucocorticoids were administered induced stimulation, suppression or unchanged ghrelin plasma levels, discrepant results that may have been derived from the use of glucocorticoids of different potencies and for variable time periods.

Our data suggest that central activation of the HPA axis, as achieved by metyrapone administration, in dissociation from a concomitant increase in circulating serum cortisol, and in fact, in the face of cortisol inhibition, was not able to stimulate ghrelin plasma levels. It is possible that to this end, high or normal cortisol levels are necessary and play a putative permissive effect to allow for catecholamine-mediated stimulation of ghrelin centrally or through activation of $\beta_{1}$-adrenergic receptors on gastric ghrelin cells $(33,34,49)$. Conversely, our data could be also interpreted as consistent with a

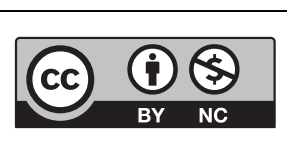

This work is licensed under a Creative Commons Attribution-NonCommercial 4.0 International License. 
direct effect of cortisol on ghrelin secretion, independent of the activation of the sympathetic nervous system.

In addition to the small number of subjects examined, our study is also limited in that in none of its phases, high cortisol serum levels were associated with suppressed plasma ACTH levels. Prior to hydrocortisone stimulation in phase 4 , ACTH levels were still substantially elevated as a result of adrenal steroidogenesis inhibition by metyrapone. Although the increase in serum cortisol levels reflecting hydrocortisone assimilation was associated with decreasing plasma ACTH levels, when peak acyl-ghrelin was achieved, ACTH was still in the normal range.

In summary, we show that increased cortisol levels secondary to ACTH stimulation or hydrocortisone administration are associated with increments in plasma ghrelin levels, whereas central stimulation of the HPA axis byblocking cortisol synthesis with metyrapone is associated with decreased plasma ghrelin levels. Collectively, this suggests that HPA-axis-mediated elevations in ghrelin plasma concentration require increased peripheral cortisol levels, independent of central elevation of ACTH and possibly CRH levels. Further studies are needed to elucidate whether a neuroendocrine feedback system between the HPA axis and ghrelin secretion exists.

\section{Declaration of interest}

The authors declare that there is no conflict of interest that could be perceived as prejudicing the impartiality of the research reported.

\section{Funding}

This research did not receive any specific grant from any funding agency in the public, commercial or not-for-profit sector.

\section{Acknowledgements}

The authors thank Etty Shabtai who assisted with the statistical analyses of this work.

\section{References}

1 Müller TD, Nogueiras R, Andermann ML, Andrews ZB, Anker SD, Argente J, Batterham RL, Benoit SC, Bowers CY, Broglio F, et al. Ghrelin. Molecular Metabolism 20154 437-460. (doi:10.1016/j. molmet.2015.03.005)

2 Yang J, Brown MS, Liang G, Grishin NV \& Goldstein JL. Identification of the acyltransferase that octanoylates ghrelin, an appetite-stimulating peptide hormone. Cell 2008132 387-396. (doi:10.1016/j.cell.2008.01.017)

3 Kojima M, Hosoda H, Date Y, Nakazato M, Matsuo H \& Kangawa K. Ghrelin is a growth-hormone-releasing acylated peptide from stomach. Nature 1999402 656-660. (doi:10.1038/45230)

4 Masuda Y, Tanaka T, Inomata N, Ohnuma N, Tanaka S, Itoh Z, Hosoda H, Kojima M \& Kangawa K. Ghrelin stimulates gastric acid secretion and motility in rats. Biochemical and Biophysical Research Communications 2000276 905-908. (doi:10.1006/bbrc.2000.3568)

5 Date Y, Nakazato M, Hashiguchi S, Dezaki K, Mondal MS, Hosoda H, Kojima M, Kangawa K, Arima T, Matsuo H, et al. Ghrelin is present in pancreatic alpha-cells of humans and rats and stimulates insulin secretion. Diabetes 200251 124-129. (doi:10.2337/diabetes.51.1.124)

6 Weikel JC, Wichniak A, Ising M, Brunner H, Friess E, Held K, Mathias S, Schmid DA, Uhr M \& Steiger A. Ghrelin promotes slow-wave sleep in humans. American Journal of Physiology: Endocrinology and Metabolism 2003284 E407-E415. (doi:10.1152/ ajpendo.00184.2002)

7 Rizzo M, Rizvi AA, Sudar E, Soskic S, Obradovic M, Montalto G, Boutjdir M, Mikhailidis DP \& Isenovic ER. A review of the cardiovascular and anti-atherogenic effects of ghrelin. Current Pharmaceutical Design 201319 4953-4963. (doi:10.2174/1381612811 319270018)

8 Geliebter A \& Aversa A. Emotional eating in overweight, normal weight, and underweight individuals. Eating Behaviors 20033 341-347. (doi:10.1016/S1471-0153(02)00100-9)

9 Chuang JC, Perello M, Sakata I, Osborne-Lawrence S, Savitt JM, Lutter M \& Zigman JM. Ghrelin mediates stress-induced food-reward behavior in mice. Journal of Clinical Investigation $2011 \mathbf{1 2 1}$ 2684-2692. (doi:10.1172/JCI57660)

10 Abizaid A, Liu ZW, Andrews ZB, Shanabrough M, Borok E, Elsworth JD, Roth RH, Sleeman MW, Picciotto MR, Tschöp MH, et al. Ghrelin modulates the activity and synaptic input organization of midbrain dopamine neurons while promoting appetite. Journal of Clinical Investigation 2006116 3229-3239. (doi:10.1172/JCI29867)

11 Perello M \& Dickson SL. Ghrelin signalling on food reward: a salient link between the gut and the mesolimbic system. Journal of Neuroendocrinology 201527 424-434. (doi:10.1111/jne.12236)

12 Maruna P, Gürlich R \& Rosická M. Ghrelin as an acute-phase reactant during postoperative stress response. Hormone and Metabolic Research 200840 404-409. (doi:10.1055/s-2008-1065329)

13 Brzozowski T, Konturek PC, Sliwowski Z, Drozdowicz D, Kwiecien S, Pawlik M, Pajdo R, Konturek SJ, Pawlik WW \& Hahn EG. Neural aspects of ghrelin-induced gastroprotection against mucosal injury induced by noxious agents. Journal of Physiology and Pharmacology 200657 (Supplement 6) 63-76.

14 Brzozowski T, Konturek PC, Konturek SJ, Kwiecień S, Drozdowicz D, Bielanski W, Pajdo R, Ptak A, Nikiforuk A, Pawlik WW, et al. Exogenous and endogenous ghrelin in gastroprotection against stress-induced gastric damage. Regulatory Peptides 2004120 39-51. (doi:10.1016/j.regpep.2004.02.010)

15 Arvat E, Maccario M, Di Vito L, Broglio F, Benso A, Gottero C, Papotti M, Muccioli G, Dieguez C, Casanueva FF, et al. Endocrine activities of ghrelin, a natural growth hormone secretagogue (GHS), in humans: comparison and interactions with hexarelin, a non naturalpeptidyl GHS, and GH-releasing hormone. Journal of Clinical Endocrinology and Metabolism 200186 1169-1174.

16 Schmid DA, Held K, Ising M, Uhr M, Weikel JC \& Steiger A. Ghrelin stimulates appetite, imagination of food, GH, ACTH, and cortisol, but does not affect leptin in normal controls. Neuropsychopharmacology 200530 1187-1192. (doi:10.1038/ sj.npp.1300670)

17 Stevanović D, Milosević V, Starcević VP \& Severs WB The effect of centrally administered ghrelin on pituitary ACTH cells and circulating ACTH and corticosterone in rats. Life Sciences $2007 \mathbf{8 0}$ 867-872.

18 Wren AM, Small CJ, Fribbens CV, Neary NM, Ward HL, Seal LJ, Ghatei MA \& Bloom SR. The hypothalamic mechanisms of the hypophysiotropic action of ghrelin. Neuroendocrinology 200276 316-324. (doi:10.1159/000066629)

19 Coiro V, Saccani-Jotti G, Minelli R, Melani A, Milli B, Manfredi G, Volpi R \& Chiodera P. Adrenocorticotropin/cortisol and http://www.endocrineconnections.org
DOI: 10.1530/EC-17-0212
(๔) 2017 The authors Published by Bioscientifica Ltd
This work is licensed under a Creative Commons Attribution-NonCommercial 4.0 International License. 
arginine-vasopressin secretory patterns in response to ghrelin in normal men. Neuroendocrinology 200581 103-106. (doi:10.1159/000085541)

20 Cabral A, Suescun O, Zigman JM \& Perello M. Ghrelin indirectly activates hypophysiotropic CRF neurons in rodents, PLOS ONE 2012 7 e31462. (doi:10.1371/journal.pone.0031462)

21 Cabral A, Portiansky E, Sánchez-Jaramillo E, Zigman JM \& Perello M. Ghrelin activates hypophysiotropic corticotropinreleasing factor neurons independently of the arcuate nucleus. Psychoneuroendocrinology 201667 27-39. (doi:10.1016/j. psyneuen.2016.01.027)

22 Shimon I, Yan X \& Melmed S. Human fetal pituitary expresses functional growth hormone-releasing peptide receptors. Journal of Clinical Endocrinology and Metabolism 199883 174-178. (doi:10.1210/ jcem.83.1.4520)

23 Barreiro ML, Pinilla L, Aguilar E \& Tena-Sempere M. Expression and homologous regulation of GH secretagogue receptor mRNA in rat adrenal gland. European Journal of Endocrinology 2002147 677-688. (doi:10.1530/eje.0.1470677)

24 Rucinski M, Ziolkowska A, Tyczewska M \& Malendowicz LK. Expression of prepro-ghrelin and related receptor genes in the rat adrenal gland and evidences that ghrelin exerts a potent stimulating effect on corticosterone secretion by cultured rat adrenocortical cells. Peptides 200930 1448-1455. (doi:10.1016/j.peptides.2009.04.016)

25 Andreis PG, Malendowicz LK, Trejter M, Neri G, Spinazzi R, Rossi GP \& Nussdorfer GG. Ghrelin and growth hormone secretagogue receptor are expressed in the rat adrenal cortex: evidence that ghrelin stimulates the growth, but not the secretory activity of adrenal cells. FEBS Letters 2003536 173-179. (doi:10.1016/S0014-5793(03)00051-6)

26 Gnanapavan S, Kola B, Bustin SA, Morris DG, McGee P, Fairclough P, Bhattacharya S, Carpenter R, Grossman AB \& Korbonits M. The tissue distribution of the mRNA of ghrelin and subtypes of its receptor, GHS-R, in humans. Journal of Clinical Endocrinology and Metabolism 200287 2988. (doi:10.1210/jcem.87.6.8739)

27 Arvat E, Maccagno B, Ramunni J, Di Vito L, Gianotti L, Broglio F, Benso A, Deghenghi R, Camanni F \& Ghigo E. Effects of dexamethasone and alprazolam, a benzodiazepine, on the stimulatory effect of hexarelin, a synthetic GHRP, on ACTH, cortisol and GH secretion in humans. Neuroendocrinology 199867 310-316. (doi:10.1159/000054328)

28 Arvat E, Ramunni J, Maccagno B, Giordano R, Broglio F, Deghenghi R, Boscaro M \& Ghigo E. Corticotropin-releasing effect of hexarelin, a peptidyl GH secretagogue, in normal subjects pretreated with metyrapone or RU-486, a glucocorticoid receptor antagonist, and in patients with Addison's disease. Neuroendocrinology 199970 200-206. (doi:10.1159/000054477)

29 Hosoda H \& Kangawa K. The autonomic nervous system regulates gastric ghrelin secretion in rats. Regulatory Peptides 2008146 12-18. (doi:10.1016/j.regpep.2007.07.005)

30 Mani BK, Osborne-Lawrence S, Vijayaraghavan P, Hepler C \& Zigman JM. $\beta 1$-Adrenergic receptor deficiency in ghrelin-expressing cells causes hypoglycemia in susceptible individuals. Journal of Clinical Investigation 2016126 3467-3478. (doi:10.1172/JCI86270)

31 de la Cour CD, Norlén P \& Håkanson R. Secretion of ghrelin from rat stomach ghrelin cells in response to local microinfusion of candidate messenger compounds: a microdialysis study. Regulatory Peptides 2007143 118-126. (doi:10.1016/j.regpep.2007.05.001)

32 Kristenssson E, Sundqvist M, Astin M, Kjerling M, Mattsson H, de la Cour CD, Håkanson R \& Lindström E. Acute psychological stress raises plasma ghrelin in the rat. Regulatory Peptides 2006134 114-117. (doi:10.1016/j.regpep.2006.02.003)

33 Gagnon J \& Anini Y. Insulin and norepinephrine regulate ghrelin secretion from a rat primary stomach cell culture. Endocrinology 2012 153 3646-3656. (doi:10.1210/en.2012-1040)
34 Engelstoft MS, Park WM, Sakata I, Kristensen LV, Husted AS, Osborne-Lawrence S, Piper PK, Walker AK, Pedersen MH, Nøhr MK, et al. Seven transmembrane $\mathrm{G}$ protein-coupled receptor repertoire of gastric ghrelin cells. Molecular Metabolism 20132 376-392. (doi:10.1016/j.molmet.2013.08.006)

35 Spencer SJ, Xu L, Clarke MA, Lemus M, Reichenbach A, Geenen B, Kozicz T \& Andrews ZB. Ghrelin regulates the hypothalamic-pituitary-adrenal axis and restricts anxiety after acute stress. Biological Psychiatry 201272 457-465. (doi:10.1016/j. biopsych.2012.03.010)

36 Rouach V, Bloch M, Rosenberg N, Gilad S, Limor R, Stern N \& Greenman Y. The acute ghrelin response to a psychological stress challenge does not predict the post-stress urge to eat. Psychoneuroendocrinology 200732 693-702. (doi:10.1016/j. psyneuen.2007.04.010)

37 Mayenknecht J, Diederich S, Bähr V, Plöckinger U \& Oelkers W. Comparison of low and high dose corticotropin stimulation tests in patients with pituitary disease. Journal of Clinical Endocrinology and Metabolism 199883 1558-1562. (doi:10.1210/ jcem.83.5.4831)

38 Misra M, Miller KK, Kuo K, Griffin K, Stewart V, Hunter E, Herzog DB \& Klibanski A. Secretory dynamics of ghrelin in adolescent girls with anorexia nervosa and healthy adolescents. American Journal of Physiology: Endocrinology and Metabolism 2005289 E347-E356. (doi:10.1152/ajpendo.00615.2004)

39 Schuessler P, Uhr M, Ising M, Schmid D, Weikel J \& Steiger A. Nocturnal ghrelin levels - relationship to sleep EEG, the levels of growth hormone, ACTH and cortisol--and gender differences. Journal of Sleep Research 200514 329-336. (doi:10.1111/j.13652869.2005.00486.x)

40 Purnell JQ, Weigle DS, Breen P \& Cummings DE. Ghrelin levels correlate with insulin levels, insulin resistance, and high-density lipoprotein cholesterol, but not with gender, menopausal status, or cortisol levels in humans. Journal of Clinical Endocrinology and Metabolism 200388 5747-5752. (doi:10.1210/jc.2003-030513)

41 Espelund U, Hansen TK, Højlund K, Beck-Nielsen H, Clausen JT, Hansen BS, Orskov H, Jørgensen JO \& Frystyk J. Fasting unmasks a strong inverse association between ghrelin and cortisol in serum: studies in obese and normal-weight subjects. Journal of Clinical Endocrinology and Metabolism 200590 741-746. (doi:10.1210/ jc.2004-0604)

42 Troisi A, Di Lorenzo G, Lega I, Tesauro M, Bertoli A, Leo R, Iantorno M, Pecchioli C, Rizza S, Turriziani M, et al. Plasma ghrelin in anorexia, bulimia, and binge-eating disorder: relations with eating patterns and circulating concentrations of cortisol and thyroid hormones. Neuroendocrinology 200581 259-266. (doi:10.1159/000087923)

43 Gluck ME, Yahav E, Hashim SA \& Geliebter A. Ghrelin levels after a cold pressor stress test in obese women with binge eating disorder. Psychosomatic Medicine 201476 74-79. (doi:10.1097/ PSY.0000000000000018)

44 Otto B, Tschöp M, Heldwein W, Pfeiffer AF \& Diederich S. Endogenous and exogenous glucocorticoids decrease plasma ghrelin in humans. European Journal of Endocrinology 2004151 113-117. (doi:10.1530/eje.0.1510113)

45 Nass R, Liu J, Patrie J, Pezzoli SS, Farhy LS, Gaylinn BD \& Thorner MO. Four-hour infusion of hydrocortisone does not suppress the nocturnal increase of circulating acyl- or desacylghrelin concentrations in healthy young adults. Journal of Clinical Endocrinology and Metabolism 201499 E1696-E1700. (doi:10.1210/ jc.2014-1210)

46 Bruder ED, Jacobson L \& Raff H. Plasma leptin and ghrelin in the neonatal rat: interaction of dexamethasone and hypoxia. Journal of Endocrinology 2005185 477-484. (doi:10.1677/joe.1.06159)

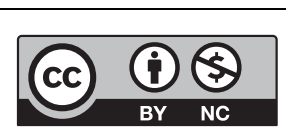

This work is licensed under a Creative Commons Attribution-NonCommercial 4.0 International License. 
47 Kageyama K, Akimoto K, Yamagata S, Sugiyama A, Murasawa S, Watanuki Y, Tamasawa N \& Suda T. Dexamethasone stimulates the expression of ghrelin and its receptor in rat hypothalamic 4B cells. Regulatory Peptides 2012174 12-17. (doi:10.1016/j.regpep.2011.11.003)

48 Proulx K, Vahl TP, Drazen DL, Woods SC \& Seeley RJ. The effect of adrenalectomy on ghrelin secretion and orexigenic action.
Journal of Neuroendocrinology 200517 445-451. (doi:10.1111/j.13652826.2005.01322.x)

49 Sapolsky RM, Romero LM \& Munck AU. How do glucocorticoids influence stress responses? Integrating permissive, suppressive, stimulatory, and preparative actions. Endocrine Reviews 200021 55-89. (doi:10.1210/edrv.21.1.0389)

Received in final form 10 October 2017

Accepted 16 October 2017

Accepted Preprint published online 16 October 2017 Published by Bioscientifica Ltd
This work is licensed under a Creative Commons Attribution-NonCommercial 4.0 International License. 